\title{
PERSEPSI DAN MOTIF PEKERJA SOSIAL TERHADAP PROGRAM PEMBERDAYAAN PEREMPUAN PSK
}

\author{
Perception \& Motive of Social Workers to the Women's Empowerment Program for \\ Commercial Sex Workers (CSW) \\ Oleh: \\ Uun Machsunah, Abu Bakar S, Ida Ri’aeni \\ Program Studi Ilmu Komunikasi \\ Universitas Muhammadiyah Cirebon \\ E-mail: machsunahuun@yahoo.com, ida.iswahyudi@gmail.com.
}

\begin{abstract}
Abstrak
Pekerja Sosial di Pusat Rehabilitasi Pekerja Seks Komersial (PSK) memerlukan keahlian berkomunikasi dalam menjalankan tugasnya. Dalam lingkungan sosial masyarakat, Pekerja sosial yang menghadapi Perempuan PSK seringkali berhubungan dengan orang-orang yang beragam dalam kehidupannya. Tidak sedikit dari perempuan PSK tersebut yang memiliki peran dalam keluarga, sebagai anak, istri atau seorang ibu dengan berbagai permasalahan. Penelitian dilakukan di Balai Rehabilitasi Sosial Karya Wanita (BRSKW) Palimanan Cirebon, yang beralamat di Jl. KH Agus Salim No 107 Rt. 06/02 Desa Palimanan Timur, Kecamatan Palimanan, Kabupaten Cirebon, Provinsi Jawa Barat. BRSKW Palimanan ini merupakan salah satu pusat rehabilitasi yang dimiliki pemerintah Provinsi Jawa Barat dan menampung siswa atau klien dari berbagai kota seperti Bandung, Tasikmalaya, Garut, Cianjur, Subang, Purwakarta, Karawang, Indramayu dan Cirebon. Program yang diberlakukan bagi perempuan PSK secara umum bertujuan untuk mengatasi permasalahan kesejahteraan sosial mereka. Secara khusus, program pemberdayaan juga berusaha memberikan ketrampilan-ketrampilan dalam berbagai bidang mulai dari agama, sosial dan seni. Pekerja sosial mengajarkan ketrampilan dan keahlian serta melakukan pendekatan dialogis terhadap perempuan PSK agar kembali hidup normal dalam lingkungan sosialnya. Dalam tugas tersebut, ada beberapa pekerja yang berstatus PNS adapula tenaga sukarelawan (honor). Setiap pekerja sosial memiliki persepsi terhadap masalahmasalah sosial yang dihadapi berkaitan dengan program pemberdayaan yang dilakukannya. Persepsi dalam komunikasi bisa sangat memengaruhi cara pekerja sosial dalam memahami dan memberi solusi terhadap masalah sosial. Kajian ini menggunakan pendekatan fenomenologi yang berusaha mengungkap makna di balik pengalaman pekerja sosial dalam menjalankan tugasnya di bidang pemberdayaan perempuan. Studi fenomenologi diharapkan mampu mengungkap pandangan setiap pekerja sosial yang bergelut dalam menunaikan tugasnya agar perannya di bidang pemberdayaan sosial bisa lebih optimal.
\end{abstract}

Kata kunci: Persepsi, Pekerja Sosial, Pemberdayaan Perempuan, Fenomenologi.

\begin{abstract}
Social Workers at Commercial Sex Workers Rehabilitation Centers (CSWs) require communication skills in performing their duties. In the social environment of the community, Social workers who confront Women CSWs are often associated with diverse people in their lives. Not a few of these PSK women who have a role in the family, as a child, wife or a mother with various problems. The research was conducted at Balai Rehabilitasi Sosial Karya Wanita (BRSKW) Palimanan Cirebon, which is located at Jl. KH Agus Salim No 107 Rt. 06/02 East Palimanan
\end{abstract}


Village, Palimanan District, Cirebon Regency, West Java Province. BRSKW Palimanan is one of the rehabilitation center owned by the government of West Java Province and accommodate students or clients from various cities such as Bandung, Tasikmalaya, Garut, Cianjur, Subang, Purwakarta, Karawang, Indramayu and Cirebon. The programs that apply to women in CSWs generally aim to address their social welfare issues. In particular, the empowerment program also tries to provide skills in various fields ranging from religion, social and art. Social workers teach skills and skills and make dialogical approaches to female CSWs to return to normal life in their social environment. In this task, there are some workers with civil servant status as volunteers (honorarium). Every social worker has a perception of the social problems faced in relation to his empowerment program. Perceptions in communication can greatly affect the way social workers understand and provide solutions to social problems. This study uses a phenomenological approach that seeks to uncover the meaning behind the experience of social workers in performing their duties in the field of women's empowerment. Phenomenology study is expected to reveal the view of every social worker who wrestle in fulfilling his duties so that his role in the field of social empowerment can be more optimal.

Keywords: Perception, social workers, woman empowerment, phenomenology.

\section{A. PENDAHULUAN}

Komunikasi berhubungan dengan perilaku manusia dan kepuasan terpenuhinya kebutuhan interaksi dengan manusia-manusia lainnya. Hampir setiap orang membutuhkan hubungan sosial dengan orang-orang lainnya, dan kebutuhan ini terpenuhi melalui pertukaran pesan yang berfungsi sebagai jembatan untuk mempersatukan manusia-manusia yang tanpa berkomunikasi akan terisolasi. Pesan-pesan itu mengemuka lewat perilaku komunikasi.

Dalam relasi sosial, selalu saja ada masalah-masalah sosial yang terjadi. Komunikasi bisa menjadi cara dalam memahami dan memberi solusi terhadap suatu masalah sosial, misalnya saja dengan pendekatan-pendekatan dialogis terhadap pelaku sosial. Dalam hal ini, salah satu masalah sosial yang terus bergulir adalah keberadaan pekerja seks komersial (PSK) di wilayah Kabupaten Cirebon yang saat ini diperkirakan mencapai 3.000 orang dinilai sangat rentan untuk turut menularkan virus HIV-AIDS di wilayah setempat.

Praktik seks bebas seperti prostitusi tanpa pengaman sangat rentan bagi penyebaran HIV-AIDS. Mobilitas mereka sangat tinggi dan bisa berhubungan kelamin dengan siapa saja. Cirebon yang termasuk daerah pantura tidak luput dari keberadaan PSK. Bahkan, menurut Sekretaris Komisi Penanggulangan AIDS (KPA) Kabupaten Cirebon, H. Deni Agustin, yang mengejutkan, lelaki hidung belang yang memanfaatkan jasa PSK tersebut sekitar 14.000 di antaranya merupakan penduduk Kabupaten Cirebon. (www.pikiranrakyat.com. 13 Juli 2011, www.dinkescirebonkab.go.id)

Hampir setiap kecamatan di Kabupaten Cirebon rata-rata melaporkan adanya kasus HIV-AIDS, dari jumlah akumulatif kasus HIV positif sampai dengan tahun 2010 yang mencapai 531 kasus, Kedawung merupakan kecamatan paling tinggi jumlahnya. Disebutkan, penularan HIV AIDS di Kabupaten Cirebon sebanyak $69 \%$ melalui hubungan seks, sisanya melalui penyalahgunaan napza suntik dan lainnya. Sebanyak $51 \%$ penularan terjadi pada orang yang sudah menikah, di samping itu 50\% kasus HIV-AIDS terdapat pada usia 21 hingga. 30 tahun. (www.dinkescirebonkab.go.id) 
Di Indonesia penanganan ekses yang ditimbulkan praktik prostitusi yang ditindak adalah PSK-nya, bukan germonya. Di sisi lain dia mengungkapkan, kasus kumulatif HIVAIDS di Jawa Barat sampai dengan tahun 2010 mencapai 5.680. Jabar termasuk peringkat ke-7 dari 15 provinsi di Indonesia yang melaporkan kasus HIV-AIDS. Masyarakat bisa membantu mensosialisasikan bahaya HIV-AIDS dengan melakukan upaya pencegahan dan penanggulangan. Pencegahan bisa dibantu dengan sosialisasi memberikan penerangan kepada sesama masyarakat lainnya.

Selain kewaspadaan terhadap HIV/AIDS, Kepolisian Resort Kota Cirebon, Jawa Barat, juga seringkali merazia sejumlah pasangan mesum. Mereka tak berkutik saat digerebek di dalam hotel kelas melati. Tak hanya itu, polisi turut merazia pekerja seks komersial (PSK), yang tetap mangkal pada Ramadhan. Wanita-wanita tersebut ditangkap di warung remang-remang di sepanjang jalur Pantai Utara. (www.metrotvnews.com, 8 Agustus 2011.) Selain di tempat tersebut, Razia juga dilakukan di tempat seperti kos-kosan dan salon yang ditengarai menjadi tempat praktek prostitusi terselubung di Kota Cirebon.(www.radarcirebon.com 29 Desember 2014, www.cirebontrust.com 12 November 2015, www.m.merdeka.com 23 November 2015)

Dalam lingkungan sosial masyarakat, pekerja sosial yang menangani PSK seringkali berhubungan dengan orang-orang yang relatif beragam dalam pekerjaannya. Tidak sedikit dari PSK tersebut yang memiliki peran dalam keluarga, sebagai anak, istri atau seorang ibu. Dibutuhkan usaha yang sungguh-sungguh untuk memahami komunikasi dalam kehidupan sehari-hari dan diharapkan mampu menjadi salah satu solusi dalam memahami masalah PSK. Realitas pengalaman yang dihadapi dalam menjalani tugas pekerja sosial dalam menghadapi PSK tersebut, akan membangun skema kognitif yang unik dari individu tentang lingkungan dengan perilakunya. Realitas yang dimaksud adalah bagaimana mereka mendapatkan perlakuan dari lingkungan, memaknai kehidupan dan bagaimana peran yang harus dipilih (role taking) ketika mereka berinteraksi dengan lingkungan.

Di dalam fenomenologi konsep makna (meaning) adalah konsep yang sangat penting. Makna, demikian tulis Smith tentang Husserl, "adalah isi penting dari pengalaman sadar manusia." Pengalaman seseorang bisa sama, seperti ia bisa sama-sama mengendari sepeda motor. Namun makna dari pengalaman itu berbeda-beda bagi setiap orang. Maknalah yang membedakan pengalaman orang satu dengan pengalaman orang lainnya. Makna juga yang membedakan pengalaman yang satu dan pengalaman lainnya. Suatu pengalaman bisa menjadi bagian dari kesadaran, juga karena orang memaknainya. Hanya melalui tindak memaknailah kesadaran orang bisa menyentuh dunia sebagai suatu struktur teratur (organized structure) dari segala sesuatu yang ada di sekitar kita. Namun begitu menurut Husserl, makna bukanlah obyek kajian ilmu-ilmu empiris. Makna adalah obyek kajian logika murni (pure logic). Pada era sekarang logika murni ini dikenal juga sebagai semantik (semantics). Maka dalam arti ini, fenomenologi adalah suatu sintesis antara psikologi, filsafat, dan semantik (atau logika murni).

Tujuan utama kajian ini adalah untuk mengeksplorasi motif pekerja sisal dalam menekuni pekerjaannya, serta persepsi pekerja sosial dalam menghadapi program rehabilitasi PSK di lingkungannya. Hal ini diupayakan dapat memahami tugas pekerja sosial dan mencari penyelesaian terhadap masalah sosial menurut pemahaman pekerja 
sosial yang terlibat di dalamnya. Perilaku komunikasi yang dimaksudkan dengan pembatasan mengenai persepsi tentang makna akan pekerjaan dan perilaku komunikasi yang terkait dengan tugas sebagai pekerja sosial.

\section{B. TINJAUAN PUSTAKA}

\section{- Persepsi}

Persepsi adalah proses menjadi sadar terhadap beberapa stimulus yang ada di sekitar, kedua (1) persepsi merupakan proses neurologis ketika sensoris stimulus diterima, diketahui, dan diakui sebagau makna yang sederhana, (2) istilah yang biasa dipakai untuk menjelaskan kontrol sensoris terhadap sesuatu yang kompleks seperti perilaku yang diinferensi dari perilaku lain, dan (3) suatu peristiwa internal yang bersifat hipotesis yang mempunyai sifat yang tidak emnentu, namun yang dikendalikan oleh sebagian besar rangsangan dari luar (kadang-kadang dipengaruhi oleh variabel seperti kebiasaan dan dorongan). Persepsi ini penting untuk mengontrol kebenaran suatu perilaku. (Liliweri, 2011: 153)

Persepsi pada dasarnya menyangkut proses informasi pada diri seseorang dalam hubungannya dengan objek stimulus. Dengan demikian persepsi merupakan gambaran arti atau interprestasi yang bersifat subjektif, artinya persepsi sangat tegantung pada kemampuan dan keadaan diri yang bersangkutan. Dalam kamus psikologi, persepsi diartikan sebagai proses pengamatan seseorang terhadap segala sesuatu di lingkungannya dengan menggunakan indera yang dimilikinya, sehingga menjadi sadar terhadap segala sesuatu yang ada di lingkungan tersebut (Dali, 1982).

Persepsi merupakan proses di mana individu memilih, mengorganisasi, dan menginterpretasi apa yang dibayangkan tentang dunia sekelilingnya. Dengan mempersepsi setiap individu memandang dunia berkaitan dengan apa yang ia butuhkan, apa yang ia nilai, apakah sesuai dengan keyakinannya dan budayanya. Semua kebutuhan yang ingin dipenuhi ini membuat persepsi individu menjalani proses personal yang rumit, karena apa yang dia persepsikan itu sangat tergantung dari sejauh mana pengaruh beragam faktor pembentuk persepsi, antara lain masa lalu individu. (Liliweri, 2011: 153)

Sangat penting bagi setiap individu melihat ke belakang, ke pengalaman masa lalu sehingga dia dapat membandingkan persepsi terkini, meneliti kembali pelbagai faktor denominasi yang mempengaruhi persepsi ini. Berarti, seorang pengirim akan mengecek setiap (makna/persepsi) terhadap pesan yang dia kirimkan agar pesan yang diterima penerima mempunyai (meaning/ perception) yang sama dengan maksud pengirim. Perbedaan persepsi di antara pengirim dan penerima ketika berkomunikasi dapat ditekan hanya jika individu mampu melihat dirinya sendiri (self-concept) dan melihat orang lain (other) sebagaimana apa adanya, hal ini karena konsep diri mempengaruhi persepsi individu terhadap orang lain. (Carolyn Mikanowicz and Shelda Shank, Communication Strategies, National Center of Contuining Education, 2009 dalam Liliweri, 2011: 153)

Persepsi sosial adalah proses dimana kita mencoba menangkap arti objek-objek sosial dan kejadian-kejadian yang kita alami dalam lingkungan kita. Manusia lebih aktif dan sulit diramalkan. Manusia juga bersifat emosional, sehingga penilaian terhadap mereka mengandung risiko. Beberapa prinsip penting mengenai persepsi sosial yang menjadi 
pembenaran atas perbedaan persepsi sosial ini adalah sebagai berikut: (Fisher dan Adams, 1994: 57-62):

1. Persepsi berdasarkan pengalaman

2. Persepsi bersifat selektif

3. Persepsi pada dasarnya bersifat dugaan

4. Persepsi bersifat evaluatif

5. Persepsi bersifat kontekstual

Pola-pola perilaku manusia berdasarkan persepsi mereka mengenai realitas (sosial) yang telah dipelajari. Persepsi manusia terhadap seseorang, objek, atau kejadian dan reaksi mereka terhadap hal-hal itu berdasarkan pengalaman (dan pembelajaran) masa lalu mereka berkaitan dengan orang, objek atau kejadian serupa. Setiap saat kita diberondong dengan jutaan rangsangan indrawi. Bila kita harus menafsirkan setiap rangsangan tersebut, kita bisa gila. Kita belajar mengatasi kerumitan ini dengan memperhatikan sedikit saja rangsangan ini (Verderber, 1978: 23).

\section{- Motif dalam Kajian Fenomenologi}

Sehubungan dengan motif-motif yang mendasari tindakan manusia, Schutz mengemukakan 2 motif yang meliputi in order to motive dan because motive sebagai dasar bagi tindakan manusia. In order to motive (motif yang menjadi tujuan) merupakan gambaran mental atas sebuah tujuan yang hendak diraih individu (Infante, et.al., 1993:79). Motif ini dipahami dalam upaya menganalisis tindakan bermakna dalam konteks internal time consciousness, dimana setiap tindakan (action) diarahkan pada sebuah proyek yang diorientasikan pada tujuan/ kesatuan tindakan (act) sebagaimana ditempatkan pada future perfect tense (Schutz, 1972:87). Sebuah tindakan dipandang mengandung in order to motive sepanjang ia dilihat sebagai rangkaian tindakan yang dilakukan sebagai sebuah proyek untuk mencapai tujuan (kesatuan tindakan) (Schutz, 1972:88).

Lebih jauh, dalam kaitannya dengan paparan Weber tentang motif, maka menjadi penting untuk mengetahui bentuk korelasi di antara konfigurasi makna dengan proyek serta tindakan-tindakan (action) yang menyertainya. Dalam hal ini, konfigurasi makna seolah menyediakan "tuntunan" atas sebuah proyek dan tindakan-tindakan yang menyertainya. Akan tetapi, konfigurasi makna tidak tersedia bagi seluruh proyek maupun tindakan. Untuk mengatasi hal ini, proyek yang tidak memiliki semacam stok makna akan dikaitkan dengan tujuan (kesatuan tindakan) di masa lalu.

Lebih lanjut Schutz (1972: 90) mengemukakan bahwa past act yang digunakan direproduksi kembali di dalam kesadaran aktor dalam upaya memformulasikan proyek baru. Semakin umum sebuah proyek, seolah kita mempunyai "pengetahuan" otomatis untuk menjalankan proyek tersebut langkah demi langkah. Dengan demikian, in order to motive merupakan konteks makna yang dibangun di atas konteks pengalaman yang tersedia dalam upaya memproyekkan tindakan.

Jika in order to motive lebih terikat dengan future perfect tense, lain halnya dengan because motive yang secara jelas tidak terikat pada future perfect tense. Secara umum, because motive (motif menjadi suatu sebab) merujuk pada suatu keadaan di masa lalu (Zeitlin, 1995: 270). Motif ini berusaha menjelaskan proyek dalam konteks pengalaman masa lalu aktor (Schutz, 1972: 91). Tidak dapat dipungkiri bahwa untuk memperoleh 
pemahaman atas because motive diperlukan pembandingan dengan motif sebelumnya, yaitu in order to motive.

Terkait dengan pembandingan kedua motif tersebut, in order to motive dicirikan oleh peran proyek sebagai faktor pendorong, di mana proyek tersebut mendorong dilakukannya tindakan-tindakan (actions) tertentu. Sementara itu, pada (genuine) because motive, pengalaman masa lalu sebelum proyek tersebut dilakukan menjadi faktor pendorong bagi dibentuknya sebuah proyek untuk mencapai tujuan (Schutz, 1972: 92). Sehingga, dapat dikatakan bahwa sementara because motive mendorong dimunculkannya sebuah proyek, in order to motive mendorong terwujudnya suatu tujuan (act) melalui proyek sebagai dasarnya.

Perlu diketahui bahwa dalam sebuah tindakan, setiap aktor hanya mempunyai kesadaran terhadap in order to motive bukan pada because motive. Selanjutnya, aktor akan benar-benar menyadari keberadaan because motive setelah ia menyempurnakan tindakan tersebut (Zeitlin, 1995: 270). Kecenderungan aktor untuk memunculkan in order to motive sebagai dasar dari tindakannya terjadi selama kesatuan tindakan atau tindakan yang telah lengkap (completed act) belum dicapai (Schutz, 1972: 89).

Di dalam interaksi sosial, in order to motive dari seorang aktor akan menjadi because motive bagi aktor lainnya (Zeitlin, 1995: 270). Hal ini mengandung makna bahwa selama proses interaksi terdapat pertukaran motif di antara aktor yang terlibat. Pengertian tercapai bila terdapat pertukaran motif khas yang sebangun (Mulyana, 2008: 81). Pemahaman atas motif orang lain (tidak secara mutlak) memungkinkan kita meningkatkan pengertian atas makna tindakan orang lain (Zeitlin, 1995: 271). Sehingga, berdasarkan interpretasi terhadap tindakan orang lain, individu dapat mengubah tindakan berikutnya agar sesuai dengan tindakan orang lain (Mulyana, 2008: 81).

\section{METODE PENELITIAN}

Metode penelitian yang digunakan adalah Metode Kualitatif dengan tradisi Fenomenologi. Pengumpulan data menggunakan metode wawancara mendalam dan observasi. Fokus kajian atau fokus penelitian fenomenologi adalah struktur kesadaran atau struktur pengalaman para subyek yang di dalam dirinya kaya pengalaman dan kesadaran Obyek penelitian fenomenologi terarah kepada struktur kesaadaran pada diri subyek atau the first person yang memiliki gagasan baru tentang realitas sosial.

Penelitian berlangsung pada medio Oktober-Juni. Peneliti mengunjungi informan dan tempat kerjanya selama beberapa kali. Awalnya mendatangi balai rehabilitasi tersebut sebagai tamu, kemudian melakukan penjajagan penelitian dengan menawarkan diri menjadi relawan di pusat rehabilitasi tersebut, mengadakan wawancara informal dan observasi mendalam. Lokasi penelitian di Balai Rehabilitasi Sosial Karya Wanita (BRSKW) Palimanan Cirebon.

Di dalam penelitian ini, secara spesifik teknik analisis data yang digunakan mengacu pada teknik analisis data fenomenologis sebagaimana dikemukakan Creswell. Pada dasarnya, teknik analisis data ini berangkat dari modifikasi metode Stevick-ColaizziKeen sebagaimana dipaparkan Moustakas (Creswell, 1998: 147). Adapun teknik analisis data tersebut meliputi: 
a. Peneliti memulai analisis dengan mendeskripsikan secara menyeluruh pengalaman subjek penelitian terhadap sebuah fenomena.

Dalam kaitannya dengan penelitian yang dilakukan, tahap ini dilakukan dengan mentranskripsikan hasil wawancara mendalam dengan para informan tentang pengalamannya sebagai pekerja sosial di BRSKW Palimanan, Cirebon.

b. Kemudian menemukan pernyataan (dalam wawancara) tentang bagaimana informan mengalami fenomena (topik yang diteliti), merinci pernyataanpernyataan tersebut (horisonalisasi data) dan memperlakukan masing-masing pernyataan secara setara, kemudian mengembangkan rincian tersebut dengan menyingkirkan pernyataan yang bersifat repetitif dan tumpang tindih.

Di dalam penelitian ini, tahap horisonalisasi dilakukan dengan merinci/menginventarisasi pernyataan-pernyataan para informan terkait bagaimana interaksi dan komunikasi yang dijalaninya sebagai terhadap pekerja sosial dalam program pemberdayaan perempuan. Masing-masing pernyataan tersebut diperlakukan secara setara dengan tidak melibatkan prasangka di dalamnya (epoche). Di samping itu, dilakukan upaya menyingkirkan pernyataanpernyataan yang bersifat repetitif dan tumpang tindih.

c. Melakukan pengelompokan terhadap pernyataan-pernyataan tersebut ke dalam unit makna (meaning unit), peneliti merinci unit-unit tersebut dan menuliskan deskripsi tekstural atas pengalaman (tentang apa yang terjadi).

Dalam penelitian ini, tahap tersebut dilakukan dengan mengklasifikasikan pernyataan-pernyataan informan tersebut ke dalam unit-unit makna dan menuliskan deskripsi tekstural yaitu tentang apa yang dialami para informan sebagai pekerja sosial di BRSKW Palimanan, Cirebon, terutama terkait interaksi dan komunikasi terhadap PSK dalam program pemberdayaan perempuan yang melahirkan persepsi informan tentang aktivitas tersebut.

d. Peneliti kemudian merefleksikan pemikirannya menggunakan variasi imajinatif atau deskripsi struktural, mencari segala makna yang mungkin dan perspektif yang divergen, serta membangun sebuah deskripsi tentang bagaimana fenomena tersebut dialami.

Di dalam penelitian ini, tahap tersebut dilakukan dengan menuliskan bagaimana para informan mengalami fenomena yang diteliti, yaitu interaksi dan komunikasi yang dilakukannya di balik pekerjaannya sebagai pekerja sosial terhadap program pemberdayaan perempuan di BRSKW Palimanan, Cirebon.

e. Peneliti membangun deskripsi secara menyeluruh atas makna dan esensi dari pengalaman yang diteliti.

Tahap ini dilakukan dengan membangun deskripsi secara menyeluruh atas makna dan esensi dari pengalaman yang berupa persepsi pekerja sosial terhadap program pemberdayaan perempuan di BRSKW Palimanan, Cirebon.

f. Proses tersebut disertai deskripsi peneliti atas bagaimana pengalaman tersebut dialami para informan/subjek penelitian (deskripsi struktural) serta deskripsi 
informan atas pengalamannya (deskripsi tekstural). Kedua deskripsi tersebut kemudian digabungkan untuk memperoleh deskripsi gabungan.

(Creswell, 1998: 147-150)

\section{PEMBAHASAN}

\section{- Profil Objek Penelitian}

Pada awalnya berdirinya, BRSKW ini merupakan asrama atau penampungan sosial, untuk para tuna sosial seperti : gepeng, yatim piatu, dan wanita tuna susila. Balai ini diberi nama Panti Pendidikan Wanita "Sedar", Khusus memberikan pendidikan kepada wanita penyandang masalah sosial tuna susila di bawah koordinasi Pemerintah Daerah Tingkat II Kabupaten Cirebon. Tahun 1964, Panti Pendidikan Wanita "Sedar", dihentikan aktifitasnya karena keterbatasan biaya dan tenaga pengelola. Tahun 1972, Pada tanggal 28 Agustus 1972, Panti Pendidikan Wanita "Sedar", menjadi Proyek Laboratories Penyantunan Rahabilitasi Wanita Tuna Susila Departemen Sosial Di Propinsi Jawa Barat. Dan diresmikan menjadi Panti Pendidikan Wanita "Silih Asih" oleh Bapak Kartono Notodarmodjo (Direktur Jenderal Kesejahteraan Anak, Keluarga dan Masyarakat).

Tahun 1979, Dengan Terbitnya SK. Menteri Sosial RI. No. 41/HUK/KEP/XI/79 Tanggal 1 November 1979, Panti Pendidikan Wanita berubah menjadi Sarana Rehabilitasi Wanita Tuna Susila. "Silih Asih' Palimanan.

Tahun 1994, Berdasarkan Surat Keputusan Menteri Sosial RI. No. 14/HUK/1994. Tanggal 24 April 1994 tentang Pembakuan nama unit Pelaksanan Tehnik Pusat / Panti/ Sasana di lingkungan Departemen Sosial, maka nama Sasanan Rehabilitasi Wanita Tuna Susila berubah menjadi Panti Sosial Karya Wanita. 'Silih Asih' Palimanan.

Tahun 2000, Pada tanggal 7 Juli 2000, Panti Sosial Karya Wanita "Silih Asih" Cirebon, diserahkan dari Pemerintah Pusat ke Pemerintah daerah Propinsi Jawa Barat. Tahun 2002, Berdasarkan peraturan daerah Propinsi Jawa Barat Nomor 5 Tahun 2002 tentang Perubahan Atas Peraturan Daerah Nomor 15 Tahun 2000 tentang Dinas Daerah Propinsi Jawa bBarat dan Peraturan Daerah Propinsi Jawa Barat Nomor 6 Tahun 2002 entang tugas pokok, fungsi dan rincian Tugas Unit Pelaksana Teknis Dinas di Lingkungan Dinas Sosial Propinsi Jawa Barat, Panti Sosial Karya Wanita "Silih Asih" Cirebon, berubah menjadi Balai Pemulihan Sosial Wanita Tuna Susila (BPSPSK) Cirebon.

Tahun 2010, Berdasarkan Peraturan Gubernur Propinsi Jawa Barat Nomor 113 Tahun 2009, 11 Desember 2009 tentang Organisasi dan tata kerja Unit Pelaksana Teknis Dinas dan Badan di Lingkungan Provinsi Jawa Barat. Balai Pemulihan Sosial Wanita Tuna Susila (BPSPSK) Cirebon, menjadi Balai Rehabilitasi Sosial Karya Wanita (BRSKW) Palimanan Cirebon.

\section{- Informan Penelitian}

Dalam mencari data yang dibutuhkan dalam penelitian, peneliti melakukan wawancara mendalam terhadap pekerja sosial dan orang-orang yang ada disekitar BRSKW yang terlibat dalam program pemberdayaan perempuan pekerja seks komersial di BRSKW. Selanjutnya didapatkan informan penelitian sebagai berikut: 
1. Bapak Asep Sukirman, Pekerja Sosial Madya di BRSKW Palimanan Cirebon. mantan Kepala BRSKW Palimanan Cirebon.

2. Bapak Nursetyo Wahyono, Pekerja Sosial Madya di BRSKW Palimanan Cirebon. Informan bertugas sebagai instruktur / Pembimbing dalam menyelenggarakan Bimbingan Keterampilan Sosial bagi Klien, menyiapkan modul bimbingan bagi para instruktur/ pembimbing.

3. Ibu Ninik Sriyani, Pekerja Sosial di BRSKW Palimanan Cirebon.

4. Bapak M. Wage Teguh Setiawan, Pekerja Sosial Madya di BRSKW Palimanan Cirebon. Informan bertugas sebagai instruktur / Pembimbing dalam menyelenggarakan Bimbingan Akhlak bagi Klien.

\section{- Motif yang Mendorong Pekerjaan Pekerja Seks Komersial (PSK)}

Latar belakang wanita memilih bekerja sebagai wanita tuna susial (WTS) atau pekerja Seks Komersial (PSK) sangat beragam. Beberapa factor sebagaimana diuraikan Kartini Kartono (2009:233 dalam Setiawan, 2017) mengenai Motif-motif yang mendorong wanita menjadi WTS sebagai mata pencaharian adalah sebagai berikut:

1) Ada nafsu seks yang abnormal.

2) Aspirasi materiil tinggi dibarengi dengan usaha mencari kekayaan melalui jalan yang mudah dan bermalas-malasan

3) Kompensasi terhadap rasa-rasa diri inferior sebagai pola adjustment yang negatif.

4) Memberontak terhadap otoritas orangtua, tab-tabu religious dan norma sosial.

5) Ada disorganisasi kehidupan keluarga atau "broken home"

6) Penundaan perkawinan jauh sesudah kematangan biologis.

7) Bermotifkan standard hidup/ekonomis yang tinggi.

8) Banyak juga gadis-gadis pecandu ganja, obat bius, dan minuman keras yang terpaksa menjual diri dan menjalankan 'profesi' pelacur secara intensif.

Para wanita yang terjun ke dunia pelacuran ada yang karena terpaksa (terdesak keadaan) serta adayang sukarela. Tetapi yang utama adalah adanya permintaan atau kebutuhan dari kaum laki-laki sehingga meningkat pula penawaran dari para pelacur.

Sementara itu, Ali Akbar (2005, dalam Setiawan, 2017) mengemukakan 6 faktir mengapa perempuan menjadi PSK yaitu:

1) Tekanan ekonomi, karena tidak ada pekerjaan, terpaksa mereka hidup menjual diri dengan jalan yang paling mudah.

2) Karena tidak puas dengan posisi yang ada. Walaupun sudah mempunyai pekerjaan, belum puas juga karena tidak bisa membeli barang-barang perhiasan yang bagus dan mahal.

3) Karena kebodohan, tidak mempunyai pendidikan atau intelegensia yang baik.

4) Cacat kejiwaan.

5) Karena sakit hati, ditinggalkan suami atau setelah dinodai kekasihnya ditinggalkan begitu saja.

6) Karena tidak puas dengan kehidupan seksualnya atau hiperseksual.

\begin{tabular}{l|l} 
Persepsi \& Motif Pekerja Sosial Terhadap Program Pemberdayaan Perempuan PSK & 19
\end{tabular} 
Masalah PSK menjadi persoalan universal dan kompleks, masalah ini menjadi isu sentral dalam permasalahan sosial.melihat fenomena begitu maraknya prostitusi sebagaimana yang ditayangkan media TV dari mulai kelas bawah, smapai masuk ke berbagai lapisan masyarakat. Salah satu usaha untuk mengatasi masalah ini dilakukan oleh Dinas Sosial Provinsi Jawa Barat melalui Balai Rehabilitasi Karya wanita (BRSKW) Cirebon dengan menyelenggarakan program usaha-usaha pelayanan kesejahteraan sosial dan rehabilitasi sosial bagi PSK dan juga eks PSK.

\section{- Monitoring Evaluasi (Monev) Program di BRSKW}

Secara lengkap, Tolok ukur keberhasilan pelayanan rehabilitasi sosial klien BRSKW dapat melalui kondisi alumni dan masyarakat, dengan ciri-ciri sebagai berikut :

A. Dilihat dari Alumni dengan indikator keberhasilan adalah:

1. Alumni tidak melakukan tindak tuna susila

2. Telah menikah dan menjadi keluarga yang sakinah

3. Sudah mempunyai kemauan dan kemampuan untuk memotivasi dirinya dan menolak melakukan kegiatan tindak tuna susila

4. Memahami, memiliki dan menguasai keterampilkan kerja tertentu yang dapat dipergunakan sebagai bekal untuk mendapat mata pencaharian bagi dirinya atau keluarganya

5. Sudah mempunyai pekerjaan yang tetap dalam bentuk usaha wiraswasta menjadi pegawai pabrik/perusahaan atau bentuk lainnya yang dapat diterima sesuai norma masyarakat

6. Sudah dapat beradaptasi dengan lingkungan sosialnya secara wajar, baik di lingkungan keluarga maupun lingkungan masyarakat dalam kegiatankegiatan kemasyarakatan khususnya kewanitaan

7. Telah memiliki kemampuan dan keterampilan untuk mempergunakan dan meningkatkan sumber-sumber pelayanan sosial sebagai salah satu bentuk partisipasi mereka untuk dapat membantu dirinya sendiri, keluarga maupun kelompok yang membutuhkannya.

8. Eks wanita tuna susila yakni mereka yang karena faktor tertentu tidak lagi melakukan pekerjaan asusila sebagai sumber mata pencaharian. Termasuk dalam hal ini:

a. Eks wanita tuna susila yang tinggal bersama dengan keluarganya;

b. Eks wanita tuna susila yang tinggal di luar lingkungan keluarganya

B. Dilihat dari Masyarakat:

1. Dapat memahami dan menghayati bahwa permasalahan sosial tuna susila bukan hanya tanggung jawab Pemerintah saja, akan tetapi juga merupakan tanggung jawab masyarakat sebagai mitra Pemerintah dalam menyelesaikan permasalahan sosial.

2. Dapat menerima kembali kehadiran eks klien dan memberikan kesempatan hidup layak secara normative di dalam lingkungan masyarakat dan mengusahakan lapangan kerja / usaha secara layak kepada mereka. 
3. Telah memiliki daya tangkal terhadap kemungkinan berkembangnya/ timbulnya permasalahan sosial tuna susila terutama di daerah asal eks penyandang tuna susila..

4. Memberikan kesempatan secara terbuka kepada Wanita Eks Tuna Susila untuk beradaptasi dalam pembangunan di masyarakat, baik di bidang kewanitaan, keagamaan dan kegiatan lainnya.

Untuk menunjang kegiatan monitoring evaluasi, BRSKW Palimanan juga melakukan pendataan terhadap klien dalam memastikan kondisi klien. Beberapa data yang berhubungan dengan klien pada monev tahun 2010-2014, diantaranya adalah tentang pendataan populasi klien berdasarkan dinas pengirim, karakteristik klien berdasarkan usia, karakteristik klien berdasarkan tingkat pendidikan, karakteristik klien berdasarkan status perkawinan, aset yang dimiliki menurut investasi penghasilan dari pekerjaan, keikutsertaan dalam kegiatan kemasyarakatan, masalah yang dihadapi dalam kegiataan ketunasusilaan, harapan tentang pekerjaan untuk kehidupan di masa yang akan datang, serta harapan kepada pemerintah.

Hasil pemeriksan dan pengobatan laboratorium sebanyak 200 klien, khusus bagi klien menderita penyakit, usus buntu, TBC, GO, Herpes, Bisul diberikan pelayanan pengobatan sampai sehat di PUSKESMAS Palimanan dan RSUD Arjawinangun. Untuk 6 klien yang hasil Laboratorium .mendapat perhatian khusus konseling dan pengobatan gratis dari Dinas Kesehatan Kabupaten Cirebon dan setelah masa bimbingan dirujuk ke Dinas Kesehatan Kabupaten dan Kota klien berasal.

Kegiatan Pasca Rehabilitasi terhadap Alumi Pasca Pemulihan Sosial adalah : Bimbingan dan Pembinaan Lanjut, Bimbingan lanjut dileksanakan oleh Petugas BPSPSK Palimanan Cirebon dan Dinas Sosial atau Petugas Sosial di daerah asal klien (alumni), Kepada keluarga dan atau orang tua alumni, Melalui perusahaan / pabrik-pabrik yang telah memperjakan alumni, Organisasi dan atau usaha perorangan yang telah atau masih memperkerjakan alumni, Informan yang memungkinkan diperoleh data secara tetap dan akurat dan Reuni dengan alumni yang di dalam Balai.

\section{- Analisis Hasil Penelitian}

Penanganan Permasalahan kesejahteraan sosial, khusunya penanganan masalah sosial wanita tuna susila tingkat kesulitannya semakin rumit. Hal ini berkaitan dengan makin meningkatnya jumlah penyandang masalah tuna susila dan kompleknya aspek penyebab seseorang melakukan penyimpangan perilaku ketunasusilaan, seiring dengan perkembangan dan pertumbuhan pembangunan khususnya di bidang industri serta IPTEK.

Berdasarkan data Dinas Sosial Provinsi Jawa Barat, Penyandang Masalah Kesejahteraan Sosial (PMKS), tuna susila di Jawa Barat pada tahun 2009 tercatat 7.726 orang. Jumlah tersebut belum termasuk mereka yang melakukan praktek / perilaku yang menunjukkan ketunasusilaan secara terselubung. Sementara target pelayanan rehabilitasi tuna susila di Jawa Barat hanya sebanyak 220 orang untuk Balai Rehabilitasi Sosial Karya Wanita Cirebon dan 120 orang untuk Unit Rumah Rehabilitasi Sosial Karya Wanita Cibadak Sukabumi. 
Secara kualitas, permasalahan sosial wanita tuna susila dapat terlihat dari kompleks permasalahan ini, mulai dari pelanggaran norma susila, agama, gangguan ketertiban, ketidakmampuan persiangan perolehan kehidupan dan penghidupan yang layak. Sehingga banyak di antara mereka yang berkompensasi dengan memanifestasikan perilakuknya melalui perilaku seksual yang tidak adekuat, melalui seks di luar nikah, melakukan seks dengan harapan mendapatkan imbalan serta perilaku lainnya.

Balai Rehabilitasi Sosial Kaya Wanita Cirebon, sebagai Unit Pelaksana Teknis Daerah Dinas Sosial Provinsi Jawa Barat, melakukan upaya peningkatan pelayanan dan rehabilitasi sosial melalui sistem Panti di mana secara fungsional bertanggung jawab atas proses rehabilitasi para penyandang masalah sosial tuna susila. Dalam pelaksanaan proses rehabilitasi ini Balai Rehabilitasi Sosial Karya Wanita Cirebon senantiasa melakukan upaya-upaya penanganan masalah tuna susila dengan:

a. Meningkatkan jangkauan pelayanan dan rehabilitasi sosial wanita tuna susila.

b. Mengembangkan dan memantapkan peran serta masyarakat,organisasi sosial dalam kegiatan-kegiatan pencegahan dan pelayanan rehabilitasi sosial penyandang masalah sosial wanita tuna susila.

c. Meningkatkan dan melengkapi sarana dan prasarana

1. pelayanan rehabilitasi sosial, baik sarana fisik, maupun personil penyelenggara dalam rangka peningkatan mutu pelayanan.

d. Mengembangkan dan meningkatkan pemusatan data serta informasi tentang permasalahan sosial wanita dan upaya penanganannya tuna susila dan upaya penangannya serta hal-hal lain yang terkait.

Untuk melaksanakan upaya tersebut Balai Rehabilitasi Sosial Karya Wanita Cirebon, melalui pekerja sosial yang bertugas di balai tersebut menempuh langkah-langkah antara lain:

a. Pemantapan administasi

b. Meningkatkan mutu pelayanan sosial bagi eks wanita tuna susila.

c. Memberikan pelayanan sosial bagi eks wanita tuna susila dan masyarakat mengenai informasi HIV / AIDS.

d. Mengembangkan pelayanan rehabilitasi melalui peningkatan kualitas sistem Panti.

e. Meningkatkan efektifitas dn jumlah sarana pelayanan.

f. Mengembangkan program pelayanan dan rehabilitasi sosial yang diarahkan pada peningkatan mutu dan kesinambungan kerja, sehingga dicapai ketuntasan.

g. Mengikutsertakan masyarakat baik tokoh masyarakat, organisasi sosial maupun pengusaha dan lingkungannya dalam sebagal kegiatan rehabilitasi sosial wanita tuna susila dalam rangka peningkatan partisipasi masyarakat.

h. Meningkatkan koodinasi operasional secara terpadu dan terintegrasi dengan unit kerja terkait.

i. Meningkatkan pendayagunaan kemampuan kerja para petugas serta pengawasan melekat disetiap tingkatan.

Program yang diberlakukan bagi perempuan PSK secara umum bertujuan untuk mengatasi permasalahan kesejahteraan sosial mereka. Secara khusus, program pem- 
berdayaan juga berusaha memberikan ketrampilan-ketrampilan dalam berbagai bidang mulai dari agama, sosial dan seni. Pekerja sosial mengajarkan ketrampilan dan keahlian serta melakukan pendekatan dialogis terhadap perempuan PSK agar kembali hidup normal dalam lingkungan sosialnya. Dalam tugas tersebut, ada beberapa pekerja yang berstatus PNS adapula tenaga sukarelawan (honor). Setiap pekerja sosial memiliki persepsi terhadap masalah-masalah sosial yang dihadapi berkaitan dengan program pemberdayaan yang dilakukannya. Persepsi dalam komunikasi bisa sangat memengaruhi cara pekerja sosial dalam memahami dan memberi solusi terhadap masalah sosial.

Berikut paparan mengenai persepsi pekerja sosial dengan menggunakan pendekatan fenomenologi, yaitu tentang Motif atau Dorongan menekuni pekerjaan sebagai Pekerja Sosial. Hasil wawancara adalah sebagai berikut:

Saya menempuh studi di kependidikan. Kuliah pendidikan Matematika. Bisa menekuni kerja menjadi peksos, awalnya kakak bekerja di Depsos Jakarta. Saya 'dicemplungkan' oleh kakak untuk menghonor. Saya tamatan SMA tahun 1989, ada lowongan di dinas sosial di sini (dulu bernama Panti Silih Asih, Cirebon). Tahun 1991 mencoba daftar, tahun 1992 mulai bekerja. Dulu memulai kerja di sini di bagian TU (tata usaha). Setelah bekerja, mulai kuliah di Unswagati jurusan Administrasi Negara. Sempat ditawari kuliah lagi di STKS sesuai pekerjaan dinas sosial, tapi pertimbangannya saya sudah menikah, jauh kalau harus keluar kota. Sampai akhirnya memilih pindah kuliah di kelas jauh sebuah Universitas di Yogykarta, karena lebih ringan dan hanya akhir pekan. Ketika ada penyesuaian golongan PNS, ijazah saya yang sarjana pendidikan tidak bisa diterima. Bisa penyesuaian, kalau saya menjadi pekerja sosial (peksos) di bidang konseling atau mengajar, sarjana pendidikan masih bisa.

Akhirnya mulai tahun 2011, mulai beralih menekuni tugas sebagai peksos. Awalnya dituntut karena SK menjadi peksos, tuntutan pekerjaan agar bisa penyesuaian. Selanjutnya saya ingin memahami dan mempelajari tugas sebagai peksos. Ingin memberi motivasi kepada anak-anak, biar mereka berhasil setelah keluar dari sini. Cukup menantang, harus buat laporan dan sebagainya. Menjadi peksos juga kadang ikut terbawa perasaan ketika menemui anak (siswa/ klien BRSKW) yang beragam. Ikut sedih, ketika ada siswa yang terjaring punya bayi masih menyusui, curhat harus menghidupi bayinya karena saat hamil dulu tidak diketahui laki-laki mana yang menjadi ayahnya. Saya katakana, mengapa bisa hamil, kamu nggak pinter, kerja begini bisa sampai hamil. Lebih sedih lagi harus pisah dengan bayinya. Kadang ingin membantu, tapi kadang saya tidak bisa banyak membantu. (Ninik Sriyani, Wawancara 20 Juli 2017)

"Awalnya saya gak suka kerja di sini. saya dulunya mo ke musik tapi mo kuliah ke situ gak boleh oleh ibu saya. Kata ibu boleh jadi musisi tapi biaya sekolah biaya sendiri. karena punya keluarga di bidang sosial saya disarankan untuk berkiprah di bidang sosial. 
Pertama kali ada jabatan fungsional sebagai peksos itu tahun 1994. Pertama, yaa ilmunya itu nggak kayak temen-temen yg lain. Praktek kerja sosial. Saya buka buku lagi. Dulu saya menganggap mereka (klien) itu seperti penjahat. Sy memperlakukan mereka tegas seperti tentara. Karena memang belum memahami. Tapi begitu saya masuk peksos saya mulai buka buku baca-baca, berarti saya punya tangung jawab ini dan ini.. saya bekerja sendiri merancang kegiatan sendiri menangani klien dan kita bikin laporan dan laporan itu akan dinilai oleh tim lain itu dilihat dari prestasi kerja kita. Itu menjadi ukuran kita oooh ternyata hasil kerja kita dari tupoksi itu kelihatan. Secara fisik ya. Itu asik. Karena saya kerja sendiri. Gak ada yg mengatur saya. Bisa mengeksplor kemampuan.

Awalnya kepada siswi saya keras. Tapi begitu masuk...baru nilai2 sosial saya muncul. Siapa sih yang ingin jd PSK? Gak ada perempuan yg mau jd psk. Krn terpaksa. Macam2 wujudnya yg mnjdikan mereka PSK. Klo awalnya dari pergaulan niih ...pergaulan bebas. Tdk ada tanggung jawab dr pacar. Tidak berani bilang ke ortu. Klo karena percekcokan rumah tangga keributan pemberian nafkah kurang, KDRT, kecewa sakit hati.

Banyak suka duka dalam menekuni pekerjaan ini. Ada siswa yang terpapar penyakit (HIV/AIDS). Sy bahkan pernah ngantar siswi yang sekarat. Sampai di rumah siswi ini sudah meninggal. Tapi orang tuanya tidak komplain karena sejak awal sudah mengetahui karakter anaknya yang meninggal. Tapi yang jelas buat saya, yang berat adalah menyampaikannya dengan tepat kepada keluarganya tentang kondisi anaknya hingga meninggal dan keluarga diharapkan bisa menerima.

Namun saat ini, tidak ada pekerjaan yang lebih membahagiakan bagi saya selain pekerjaan yang saya tekuni sekarang ini...

(M.Wage)

Dari hasil wawancara tersebut, didapatkan motif pekerja sosial yaitu: 1) Motif Tuntutan Kenaikan Jenjang Karier. Dalam hal ini tuntutan akan karier yang sesuai dengan latar pendidikan informan mengharuskan ia bekerja menjadi peksos. Yaitu dalam penyataan "(Saya) Awalnya dituntut karena SK menjadi peksos, tuntutan pekerjaan agar bisa penyesuaian.” 2) Motif Manfaat. Bisa dikatakan bahwa ini merupakan motif lanjutan setelah menekuni pekerjaan sebagai peksos, di mana informan ingin memberikan manfaat kepada siswa dengan terus memberikan motivasi bagi keberhasilan klien melalui program rehabilitasi. Tertuang dalam statement informan, "Ingin memberi motivasi kepada anakanak, biar mereka berhasil setelah keluar dari sini”.(3) Motif Pengabdian, adalah motif di mana pekerja sosial menganggap apa yang ia lakukan adalah memberikan kebaikan kepada klien/siswa, dengan berbagai pengorbanan. Salah satunya kisah ketika mengantarkan klien yang sakit dalam keadaan kritis ke rumahnya hingga akhirnya meninggal. Statement "tidak ada pekerjaan yang lebih membahagiakan bagi saya selain 
pekerjaan yang saya tekuni sekarang ini...” adalah makna dari pengabdian terhadap pekerjaan pekerja sosial tersebut.

Persepsi Pekerja Sosial tentang Gambaran Program Pemberdayaan Perempuan di BRSKW, adalah sebagai berikut:

BRSKW yang dahulu bernama PRW Silih Asih. Pada era Presiden Gusdur diganti nama menjadi BRSKW dilimpahkan ke provinsi Jawa Barat. Tiap angkatan menampung 110 siswa, dua periode selama setahun. Dalam proses pembelajaran di kelas, siswi diajari antara lain keterampilan-keterampilan yang berkaitan dengan bidang perempuan yakni merias pengantin, gunting rambut (salon) dan tata boga seperti memasak, membuat kue, serta menjahit. Diharapkan setelah menjalani "sekolah karantina" di BRSKW siswi tidak melakukan aktivitasnya yang dulu sebagai PSK.(Asep Sukirman)

Program pembinaan fisik, mental, sosial, ketrampilan. Sejak dulu (kurikulumnya) sampai skrg tidak berubah. Fisik itu kegiatannya antara lain olah raga, pemeriksaan kesehatan, pemenuhan kebutuhan khusus wanita, kebutuhan makan sehari hari, pelayanan asrama, uang saku klien. Klo mental isinya yaa bimbingan akhlak...... Ada 18 materi, selama seminggu.Sasaran program ini adalah PSK atau WTS, Perek (Perempuan Eksperimen), Mucikari/Germo, serta Masyarakat sekitar dan perorangan yang bisa berperan aktif mengatasi masalah tuna susila. (Nursetyo W)

Yang masuk ke sini 80 persen karena faktor ekonomi. Yg menengah ke atas dijamin tidak akan masuk ke sini. Yang (razia) diambil kelas jalanan, klo yg di hotel yg kelas melati. Pada umumnya mereka janda. Ada yang bersuami, termasuk gadis tapi paling 2 persen. Kadang bisa sampai 30 atau 40 persen. Karena setiap thn setiap angkatan beda2. (M. Wage)

Selanjutnya, Persepsi Pekerja Sosial tentang Pekerjaannya, yaitu bagaimana pekerja sosial memaknai pekerjaannya, peneliti mendapati hasil dari informan sebagai berikut:

Seksi Rehabilitasi Sosial adalah salah satu bagian yang ada dalam BRSKW dan berhubungan langsung dengan pembinaan klien. Tugas dari Seksi Rehabilitasi Sosial adalah mem punyai tugas pokok melaksanakan pelayanan bimbingan fisik, mental, sosial dan keterampilan klien wanita tuna susila.

Selain itu, saya juga bertugas membuat Desain perancangan virtual class, Modul: Bimbingan Ketrampilan Sosial bagi Klien BRSKW Cirebon serta Silabi Bimbingan. (Nursetyo W)

Hasil penelitian yang didapatkan dari informan mengenai Persepsi Pekerja Sosial tentang diri PSK adalah sebagai berikut:

Tidak ada siswi di BRSKW yang betah, maunya kabur melulu. (Asep S) 
Faktor menjadi PSK krn internal dan eksternal. Ada yg krn faktor ekonomi, sakit hati, ada jg yg krn ketagihan, ada jg yg tipenya mngejar terus jd bukan krn masalah uang tp krn suka dg yg dikejarnya, ada jg yg krn punya penyakit dan harus dioperasi tapi tidak punya uang untuk berobat. Masalahnya biasanya kompleks, tidak tunggal. (Nursetyo W)

Tidak ada orang yg mau jd PSK. Misalnya dari pergaulan, dari pacar...kalau yg berumah tangga diselingkuhi, dan seterusnya. (M. Wage)

Siswa atau anak-anak yang masuk ke balai ini banyak yang tidak mengaku. Mereka kerja di panti pijat, tapi tidak dengan plus plus. Bukan 'jitot' atau pijat ngentot sebutan mereka, pijat aja ngakunya. Jadi komunikasi yang dilakukan untuk mendata mereka tidak cukup sekali saja. Saat masuk ditanyai beberapa hal, didata. Selanjutnya sekitar dua pekan kemudian didekati lagi, didata kembali. Misal ada yang awalnya tidak mengaku, kemudian setelah diidentifikasi ulang, diajak ngobrol lagi, mengaku bahwa ia bekerja, istilahnya jadi 'pemain'. Biasa dibayar 200 ribu sekali melayani konsumen. Itu bersih. Biasa di hotel-hotel kelas melati, kalau di Cirebon yang dekat polresta, ada hotel baru.

Kelompok siswa sebelum ini, ada yang berasal dari Saritem, Bandung. Itu enak, anak-anaknya jujur. Langsung mengaku. Cerita terbuka. Komunikasinya enak. Salah satunya mereka bercerita biasa dibayar 150 ribu per pelanggan. Itu untuk maksimal setengah jam. Lebih dari itu pelanggannya bisa kena cas. Bersih hanya dapat 75 ribu. Dibagi untuk GM (ji-em atau germo atau mamihnya) 50 ribu, lalu untuk bodyguardnya 25 ribu. Rata-rata sehari 10 pelanggan. Semua uang tersebut disetorkan ke mamihnya. Jadi si anak nggak pegang uang. Nanti kalau butuh, untuk kirim ke keluarga, baru diberikan. Seperti gajian.

Anak yang dari saritem ini cantik. Kasihan, dia terjerumus begini awalnya ditawari kerja, dikira dapat di perusahaan apa, tahunya ke saritem. Keluarganya nggak tahu. Tahunya kerja. Karena dikirim bulanan. Dari gadis terjerumus ke kerja begini. Saya sempat nanya, apa bisa kuat sampai sehari 10 orang begitu. Dia jawab buka-bukaan, mainnya tidak pakai nafsu. Jadi melayani nggak pakai perasaan, itu menurutnya nggak akan capek. Kalau terpancing, satu kali juga lelah. Kasian kan, sehari harus sampai 10 orang, cantik tapi 'jebol'. (Ninik Sriyani, Wawancara 20 Juli 2017)

Kendala dan Masalah yang dihadapi Pekerja Sosial dalam Mengelola Program di BRSKW Palimanan Cirebon, informan memaparkan sebagai berikut:

Bukannya tidak disadari lembaga kami tapi faktor anggaran (dana) yang menjadi kendala. Pada 2012, minimnya anggaran dari dinas provinsi. Selain itu, ketika ditanyakan tentang biro konsutasi, ternyata juga tidak ada. Padahal biro ini sangat diperlukan untuk menampung keluh kesah siswi dan semua permasalahan 
yang dialami mereka. Biro ini bias meminimalisir masalah serta mengantisipasi dan mengurai (memecahkan) masalah-masalah yang menimpa para siswi, apapun masalahnya.

Selain itu, ada penyakit-penyakit yang diidap siswi: gonorhoe, HIV/ Aids. Penyakit ini cenderung ada di setiap angkatan, berkisar antara 2,3,4 sampai 5 orang siswi. Siswi berasal dari razia dinas sosial provinsi di Bandung, sekitar $50 \%$ jumlah terbanyak dari hasil razia, selebihnya(sisanya) berasal dari Indramayu, kabupaten dan kota Cirebon.(Asep S)

Program tidak selalu berjalan lancar. Kendalanya, Faktor internal dan eksternal. Misalnya ada oknum aparat yang istrinya kena razia dan masuk membopong paksa. Dari hasil razia itu di sini terima bersih. sudah diseleksi. Kendalanya di sana sudah dirazia sbnrnya di sini sudah terima bersih $d r$ hasil seleksi tp kendalanya di sana sudah dirazia keburu ada oknum2 yg mengambil memanfaatkan situasi, supaya tidak mubazir. semuanya dibawa ke sini supaya kelihatan hasilnya banyak. Ya akhirnya di sini yg ketempuhan. Kdg ada yg hamil, kena penyakit, orang yg udah bekerja, ada yg msh gadis. semuanya dibawa ke sini. Semua yg kejaring diperiksa.

Kesulitan yg dihadapi adalah faktor internal klien jg dr pelayanan yg kurang maksimal. Tidak selalu bisa memenuhi kebutuhan ideal bagi klien. Misalnya biasanya kecukupan di sini terbatasi. Kendala lainnya adalah faktor psikologis, ada malesnya, ada berontak2nya. Ya tugas kami untuk berusaha mengatasi masalah2 tersebut. Terutama motivasi. Sampai skrg masih ada klien yg berusaha kabur. Itu misalnya krn klien msh punya anak kecil, atau orang tua yg sakit.. (Nursetyo W)

Pandangan Pekerja Sosial mengenai Efektivitas Program Pemberdayaan Perempuan, adalah sebagai berikut:

Mereka yang dibekali dengan keterampilan dan disesuaikan dengan minat (bakat) yang mereka miliki ketika keluar mereka akan disupport (diberikan) fasilitas dasar untuk mengembangkan diri ketika berbaur kembali dengan masyarakat. Misalnya yang hobi dan punya kecenderungan minat menjahit akan diberikan mesin jahit. Namun faktanya, para siswi sampai sejauh ini belum Nampak jelas "hasil” yang diharapkan setelah lulus dan keluar dari karantina BRSKW.

Hal ini berkaitan dengan tidak adanya pemantauan dari BRSKW setelah mengikuti program belajar. Pihak BRSKW lepas tangan, tidak ada wajib lapor dari siswi, tidak ada kontrol maupun pendampingan agar siswi tidak terjun lagi ke dunia PSK yang menjadi lahan nafkah hidup keluarganya. (Asep S) 
Ada monitoring setelah klien keluar, setelah paling tidak 3 bln setelah keluar dr sini. harus ada anggaran. Ada monev sekian kali. Nanti dilaporkan hasil dari monev itu apa. Misalnya tanggapan dinas ini apakah sdh melakukan pembinaan atau monitoring. Mereka ada di tempat atau tidak. Klo mau ke daerah ya butuh wkt cukup panjang skrg sdh beda jaman. Skrg cukup dg kabupaten dg kota.. Klo dulu itu harus ketemu langsung dg mantan klien. Harus ke bawah, hrs nyari. Klo enggak ada di sini nanti nyari misalnya ke tempat biasanya nongkrong. Misalnya di kontrakannya siang ini gak ada....kita cari n temui malamnya. Itu kan ada jaringannya, temen2 deketnya. Itu klo pingin ketemu. Dulu harus nyari harus ketemu langsung klo mo kasi bantuan kelompok bersama. (Nursetyo W)

Pola-pola perilaku manusia berdasarkan persepsi mereka mengenai realitas (sosial) yang telah dipelajari. Persepsi manusia terhadap seseorang, objek, atau kejadian dan reaksi mereka terhadap hal-hal itu berdasarkan pengalaman (dan pembelajaran) masa lalu mereka berkaitan dengan orang, objek atau kejadian serupa.

Gambaran mengenai persepsi pekerja sosial tersebut akan menghasilkan kategorisasi data tentang pemaknaan peksos terhadap apa yang dilakukannya, yaitu mengenai persepsi peksos tentang program pemberdayaan perempuan PSK, persepsi peksos tentang pekerjaannya, persepsi peksos tentang diri PSK, persepsi peksos tentang kendala dalam pengelolaan program, dan efektivitas keberlangsungan program di pusat rehabilitasi. Persepsi tersebut berdasarkan pada persepsi sosial, di mana proses dimana kita mencoba menangkap arti objek-objek sosial dan kejadian-kejadian yang kita alami dalam lingkungan kita. Merujuk (Fisher \&Adam, 1994) pada persepsi berdasarkan pengalaman, selektif, pada dasarnya bersifat dugaan, bersifat evaluatif dan bersifat kontekstual.

Merujuk pada teori persepsi antar pribadi, persepsi manusia juga dipengaruhi oleh pengharapan (expectation)nya. Bila orang telah belajar mengharapkan sesuatu untuk terjadi, mereka akan mempersepsi informasi yang menunjukkan pada mereka bahwa apa yang mereka harapkan telah terjadi. Mereka tidak akan memperhatikan informasi yang menunjukkan pada mereka bahwa pengharapan mereka tidak terpenuhi (Goodacre dan Follers, 1987: 31). Emosi kita jelas sangat mempengaruhi persepsi kita. Dalam hal ini, persepsi pekerja sosial di atas jika merujuk pada beberapa prinsip penting mengenai persepsi sosial yang menjadi pembenaran atas perbedaan persepsi sosial ini adalah sebagai berikut: (Fisher dan Adams, 1994: 57-62): Persepsi berdasarkan pengalaman, Persepsi bersifat selektif, Persepsi pada dasarnya bersifat dugaan, Persepsi bersifat evaluative, Persepsi bersifat kontekstual. Persepsi setiap individu pekerja sosial dalam memandang dunia pekerjaan yang ia geluti praktis berbeda. Hasil penelitian didapatkan, bahwa persepsi pekerja sosial tentang program pemberdayaan sosial, adalah: (1) Program pembinaan fisik, mental, sosial, ketrampilan terhadap siswa/klien di pusat rehabilitasi adalah program yang membina seluruh aspek kebutuhan klien. Keseluruhan prog ram ini dianggap peksos sebagai program terbaik dengan kurikulum yang ideal. (2) Pekerja sosial memandang menjadi PSK adalah pilihan karena desakan ekonomi dan beragam alasan lain, karenanya peksos menyadari perlu memiliki empati tinggi dalam menjalani pekerjaan di pusat rehabilitasi. (3) Kendala dalam menjalankan program rehabilitasi siswa meliputi aspek internal dan eksternal klien, kondisi psikologis dari klien, penyakit yang diderita klien 
karena menjalani kehidupan sebagai PSK, adanya keluarga dan aparat yang tidak mendukung berlangsungnya program rehabilitasi. Peksos pun menyadari pelayanan yang diberikan tidak selalu bisa memenuhi kebutuhan ideal klien. (4) Adanya bantuan fasilitas dasar setelah siswa menjalani masa 3 bulan rehabilitasi, namun untuk monitoring dan evaluasi program tidak lagi menjadi tanggungjawab BRSKW melainkan dinas sosial terdekat dengan tempat tinggal klien. Identitas klien dirahasiakan agar bisa menjalani kembali kehidupan sosial yang normal.

\section{E. SIMPULAN}

Dari kajian yang dilakukan peneliti menemukan bahwa program yang dilakukan terhadap klien di BRSKW meliputi bimbingan terhadap aspek fisik, mental, sosial dan keterampilan wanita tuna susila atau PSK; pelaksanaan bantuan psikososial, pendampingan dan bantuan hukum klien wanita tuna susila. Adapun simpulan dari penelitian ini adalah sebagai berikut: Motivasi pekerja sosial (peksos) dalam program pemberdayaan perempuan di Pusat Rehabilitasi BRSKW Cirebon adalah (1).Motif Tuntutan Kenaikan Jenjang Karier. Dalam hal ini tuntutan akan karier yang sesuai dengan latar pendidikan informan mengharuskan ia bekerja menjadi peksos. (2) Motif Manfaat. Bisa dikatakan bahwa ini merupakan motif lanjutan setelah menekuni pekerjaan sebagai peksos, di mana informan ingin memberikan manfaat kepada siswa dengan terus memberikan motivasi bagi keberhasilan klien melalui program rehabilitasi. (3)Motif Pengabdian, adalah motif di mana pekerja sosial menganggap apa yang ia lakukan adalah memberikan kebaikan kepada klien/siswa, dengan berbagai pengorbanan.

Selanjutnya, persepsi pekerja sosial tentang program pemberdayaan sosial, adalah: (1) Program pembinaan fisik, mental, sosial, ketrampilan terhadap siswa/klien di pusat rehabilitasi adalah program yang membina seluruh aspek kebutuhan klien. Keseluruhan prog ram ini dianggap peksos sebagai program terbaik dengan kurikulum yang ideal. (2) Pekerja sosial memandang menjadi PSK adalah pilihan karena desakan ekonomi dan beragam alasan lain, karenanya peksos menyadari perlu memiliki empati tinggi dalam menjalani pekerjaan di pusat rehabilitasi. (3) Kendala dalam menjalankan program rehabilitasi siswa meliputi aspek internal dan eksternal klien, kondisi psikologis dari klien, penyakit yang diderita klien karena menjalani kehidupan sebagai PSK, adanya keluarga dan aparat yang tidak mendukung berlangsungnya program rehabilitasi. Peksos pun menyadari pelayanan yang diberikan tidak selalu bisa memenuhi kebutuhan ideal klien. (4) Adanya bantuan fasilitas dasar setelah siswa menjalani masa 3 bulan rehabilitasi, namun untuk monitoring dan evaluasi program tidak lagi menjadi tanggungjawab BRSKW melainkan dinas sosial terdekat dengan tempat tinggal klien. Identitas klien dirahasiakan agar bisa menjalani kembali kehidupan sosial yang normal.

\section{DAFTAR PUSTAKA}

Abdurahman dan Maman. (1988). Geografi Perilaku: Suatu Pengantar Studi Tentang Persepsi Lingkungan. Dirjen Dikti, Jakarta.

Alimul, Aziz. Pengantar Kebutuhan Dasar Manusia. Jakarta: Salemba Medika. 2007. Arnold Junaedi, Fajar (2007). Komunikasi Massa, Pengantar Teoritis. Yogyakarta, Santusa 
Basrowi dan Sukidin. 2002. Metode Penelitian Kualitatif Perspektif Mikro. Surabaya: Insan Cendekia.

Beebe, Steven A. Susan J. Beebe and Mark V. Redmond. 1996. Interpersonal Communication: Relating to Others. Boston: Allyn and Bacon.

Berger, Peter L. dan Thomas Luckmann. Tafsir Sosial atas Kenyataan: Risalah tentang Sosiologi Pengetahuan. Jakarta: LP3ES. 1990.

Berger, Peter. Invitation to Sociology, A Humanistic Perspective. Garden City, Doubleday. 1963.

Bloom, B.S. Krathwohl, D.R., dan Masia, BB., (1973), Taxonomy of Educational Objectives : Book 1 Cognitives Domain, London : Longman Group.

Bogdan, Robert dan Steven J. Taylor. 1992. Pengantar Metoda Penelitian Kulitatif, terjemahan Arif Furchan. Surabaya: Usaha Nasional.

Brouwer, M.A.W. Psikologi Fenomenologis. Penerbit Gramedia Utama, Jakarta. 1984.

Burns, R.B. 1993. Konsep Diri: Teori, Pengukuran, Perkembangan dan Perilaku. Terjemahan Eddy. Jakarta: Arcan.

Burton, Graeme. 2000. Talking Television: An Introduction to the Study of Television. London.

Calhoun, James F. Dan Joan Ross Acocella. 1995. Psikologi tentang Penyesuaian dan Hubungan Kemanusiaan. Terjemahan R.S. Sarmoko. Semarang: IKIP Semarang Press.

Camp, W.G., Daugherty, T.B., and Kirts, Carla, (1991), Managing Our Natural Recources, USA: Delmar Publishers Inc.

Creswell, John W. 1998. Qualitative Inquiry and Research Design: Choosing Among Five Traditions. Thousand Oaks, California: Sage Publication.

Devito, Joseph A. 2004. The Interpersonal Communication Book: Tenth Edition. Boston: Pearson Education.

Drijarkara, N. Percikan Filsafat. Jakarta: PT Pembangunan, 1964

Dusek, Jerome B. 1996. Adolescent Development and Behaviour $3^{\text {rd }}$ Edition. New Jersey: Prentice Hall.

Fisher, B. Aubrey, 1986, Teori-teori Komunikasi. Penyunting: Jalaluddin Rakhmat, Penerjemah: Soejono Trimo. Bandung: Remaja Rosdakarya.

Fremont E. Kast, James E. Rosenzweig (2002), Organisasi dan Manajemen 1, Jakarta, Bumi Aksara.

Gibson, James L; Ivancevich, J.M, Danelly, Jh.JR. (1988). Organisasi dan manajemen: struktur, prilaku dan proses, Terjemahan Djoerban wahid. Jakarta: Aksara Baru

Infante, Dominic A., Andrew S. Rancer, Deanna F. Womack. 1993. Building Communication Theory: Second Edition. Illinois: Waveland Press.

Kuswarno, Engkus. 2009. Metodologi Penelitian Komunikasi Fenomenologi: Konsepsi, Pedoman, dan Contoh Penelitiannya. Bandung: Widya Karya.

Kuswarno, Prof Dr Engkus. Metode Penelitian Komunikasi: Fenomenologi-Konsepsi Pedoman dan Contoh Penelitian. Widya Padjadjaran, Bandung. 2009.

Liliweri, Alo. 2011. Komunikasi Serba Ada, Serba Makna. Jakarta, Kencana.

Lindlof, Thomas R. dan Bryan C. Taylor. 2002. Qualitative Communication Research Methods: $2^{\text {nd }}$ Edition. Thousand Oaks, California: Sage Publication. 
Littlejohn, Stephen W (1994). Theories of Human Communication, 5th Edition. Belmont CA, Wadsworth Publising Company

Littlejohn, Stephen W. 2002. Theories of Human Communication: Seventh Edition. Albuquerque, New Mexico: Wadsworth.

McQuail, Denis (2002). McQuail's Mass Communication Theory. London, Sage Publications.

Moleong, Lexy J. 2005. Metodologi Penelitian Kualitatif Edisi Revisi. Bandung: Remaja Rosdakarya.

Moustakas, Clark. 1994. Phenomenological Research Methods. Thousand Oaks, California: Sage Publications.

Mulyana, Deddy dan Jalaluddin Rakhmat (Ed). 2010. Komunikasi Antarbudaya: Panduan Berkomunikasi dengan Orang-orang Berbeda Budaya. Bandung: Remaja Rosdakarya.

Mulyana, Deddy. 1999. Nuansa-nuansa Komunikasi: Meneropong Politik dan Budaya Komunikasi Masyarakat Kontemporer. Bandung: Remaja Rosdakarya. . 2001. Metodologi Penelitian Kualitatif: Paradigma Baru Ilmu Komunikasi dan Ilmu Sosial Lainnya. Bandung: Remaja Rosdakarya. . 2011. Komunikasi Lintas Budaya. Bandung: Remaja Rosdakarya.

Myers, David G. 2005. Social Psychology: $8^{\text {th }}$ Edition. New York: McGraw-Hill.

Pearson, Judy, Paul Nelson, Scoot Titsworth, Lynn Harter. 2006. Human Communication $2^{\text {nd }}$ Edition. New York: McGrawHill.

Perlmutter, Marion dan Elizabeth Hall. 1985. Adult Development and Aging. New York: John Wiley and Sons.

Peter Salim, (1985), The Contemporary Englihs-Indonesia Dictionary, Jakarta: Modern English Press.

Rakhmat, Jalaluddin. 2004. Psikologi Komunikasi. Bandung: Remaja Rosdakarya.

Ritzer, George (Ed). 2005. Encyclopedia of Social Theory: Volume 1. Thousand Oaks: Sage Publications.

Robbins. StephenP. (2002), Perilaku Organisasi 1, Konsep, Kontroversi, Aplikasi, Jakarta, PT.Prenhallindo,

Schutz, Albert. The Phenomenology of the Social World. Heinemann Educational Books Ltd, London. 1972.

Schutz, Alfred. 1972. The Phenomenology of the Social World. Translated by George Walsh and Frederick Lehnert. London: Heinemann Educational Books.

Setiawan, Mohamad Wage Teguh. 2017. Laporan Kegiatan Pekerja Sosial Bulan Mei 2017. BRSKW Dinas Sosial Pemerintah Daeran Provinsi Jawa Barat.

Setiawan, Mohamad Wage Teguh. 2017. Modul Penerapan Bimbingan Akhlak Bagi Wanita Tuna Susila di Balai Rehabilitasi Karya Wanita Cirebon. BRSKW Dinas Sosial Pemerintah Daerah Provinsi Jawa Barat.

Smith, David Woodruff. Husserl. London, Routledge. 2007. Hal.190

Sobur, Alex. 2003. Psikologi Umum: Dalam Lintasan Sejarah. Bandung: Remaja Rosdakarya.

Soekanto, Soerjono. 2002. Sosiologi Suatu Pengantar. Jakarta: Raja Grafindo Persada. 
Suprayogo, Imam dan Tobroni. 2003. Metodologi Penelitian Sosial-Agama. Bandung: Remaja Rosdakarya.

Taylor, Shelley E., Letitia Anne Peplau, David O Sears. 2009. Psikologi Sosial. Jakarta: Kencana Prenada Media Group.

Tim BRSKW. Bagan tujuan standarisasi BRSKW, Palimanan Cirebon. Tidak Dipublikasikan.

Tim BRSKW. Data Isian Klien BRSKW Cirebon, Tidak Dipublikasikan.

Tim BRSKW. Desain perancangan virtual class, BRSKW Palimanan Cirebon. Tidak Dipublikasikan.

Tim BRSKW. Evaluasi PRG PKS, Tidak Dipublikasikan.

Tim BRSKW. Panduan Kerja 2010, BRSKW Palimanan. Tidak Dipublikasikan.

Tim BRSKW. Profil BRSKW Palimanan Cirebon 2011, Tidak Dipublikasikan.

Tim BRSKW. Bahan Paparan BRSKW Palimanan Cirebon 2017, Tidak Dipublikasikan.

Tim BRSKW. Data Klien BRSKW Palimanan Cirebon 1972 sampai 2017, Tidak Dipublikasikan.

Tubbs, Stewart L. Dan Sylvia Moss. 2000. Human Communication: Konteks-konteks Komunikasi. Terjemahan Deddy Mulyana dan Gembirasari. Bandung: Remaja Rosdakarya.

Verderber, Rudolph F. and Kathleen S. Verderber. 2005. Communicate. Belmont: Thompson Wadsworth.

Wahyono, Nursetyo A. Ks. Modul: Bimbingan Ketrampilan Sosial bagi Klien BRSKW Cirebon (1 dan 2). Tidak Dipublikasikan.

Wahyono, Nursetyo. Silabi Bimbingan, Jam latihan bimbingan, Pedoman kerja 09. Tidak Dipublikasikan.

West, Richard dan Lynn H. Turner. 2008. Pengantar Teori Komunikasi: Analisis dan Aplikasi Edisi 3. Terjemahan Maria Natalia Damayanti Maer. Jakarta: Salemba Humanika.

Wood, Julia T. 2008. Communication Mosaics: An Introduction to The Field of Communication. Belmont: Thompson Wadsworth.

Zeitlin, Irving M. 1995. Memahami Kembali Sosiologi: Kritik terhadap Teori Sosiologi Kontemporer. Terjemahan Anshori dan Juhanda. Yogyakarta: Gadjah Mada University Press.

Artikel terjemahan dari Alfred Schutz, Phenomenology and Research Methodology for Information Behaviour Research Oleh Professor T.D. Wilson (A paper delivered at ISIC4 - Fourth International Conference on Information Seeking in Context, Universidade Lusiada, Lisbon, Portugal, September 11 to 13, 2002) 